\title{
Recent Research on Bronze Age Metal Deposits in Poland
}

\author{
Justyna Baron* \\ Institute of Archaeology, Wrocław University, Poland
}

Submission: February 04, 2017; Published: March 21, 2017

*Corresponding author: Justyna Baron, Institute of Archaeology, Wrocław University, ul. Szewska 48, 50-139 Wrocław, Poland, Tel: +48-713755-187; Fax: +48 713752 882; Email: justyna.baron@uwr.edu.pl

\section{Abstract}

The review aims at presenting recent research directions in studies on Bronze Age metal deposits in the area of contemporary Poland. Starting from a brief presentation of mainopinions what the deposits are, I will bring some examples of recent studies involving interesting questions. In general, the research is focused on two main areas: one is a natural and cultural context of deposits while the other one, with the application of use-wear analysis, refers to biographies of particular objects.

Keywords: Bronze Age; Poland; Landscape studies; Use-wear analysis; Bronze; Deposits

\section{Introduction}

Introducing metals into humans life - copper and gold first, followed by bronze and iron - resulted in multifaceted transformations of the past societies. One of the most fascinating phenomena are deposits of metal objects. There are many definitions among scholars of such finds but in general, they are understood as collections of at least two artefacts deposited deliberately apart from funeral contexts [1]. The deposits containing mostly tools and weapons become one of the most recognized characteristic of the European Bronze Age (in Central Europe: ca. 2350-750 BC) starting nearly from its initial stages i.e. ca. 2350 BC [2]. From the first discoveries they arouse high interest both among professionals and wider public. Along with first reports on the deposits, the interpretations of what they are varied and, interestingly, the different opinions resulted mostly not from the contexts or content of the collections but from the cultural and geographic background of the scholars. Bradley [3] divides the interpretations into three general groups (war, economy or ritual) and notices each interpretation prevails in three discrete European regions of specific historical background. He argues that in Central Europe, the archaeological explanations usually refer to wars and conflicts, while in Western Europe this is economy that stands beyond deposits, and in Northern Europe - ritual. His opinion was then confirmed in a detailed study on Bronze Age deposits in Poland by Blajer h [4] who admits the "war interpretation" has been the most common opinion in the Polish archaeological literature for decades. Also the notion "deposit" (depozyt in Polish) is considered to be rather neutral in terms of interpretation and thus less common as compared to "hoard" (skarb in Polish - same word for hoard and treasure) which suggests precious objects hidden and meant to be found again. The main analytical tool in studies on deposits was classification of metal objects and their precise chronology. Then, the provenance of selected, imported artefacts was studied, sometimes accompanied with analyses of their chemical composition, that resulted in reconstruction of possible trading routes. Context and wider interpretations were rather beyond main research interests. The first collection of papers putting the leading question on the meaning and significance instead of the typology and chronology of the deposits was published in 1997 [5].

Recent studies have developed into two main directions: context and use, thisresulted in analysing and interpreting the deposits on macro- and microscale. The first one is focused on context and can be generally connected with a landscape archaeology. Cultural and settlement context of deposits understood not only as a random set but a complete, intentionally and carefully selected collection has been a subject of detailed studies. The "settlement approach" for younger stages of the Bronze Age is represented in a recent book by Blajer [6] who argues there is a close connection between deposits and their distribution within the settlement networks. That view is shared by Maciejewski [1] who proved in hisstudies, that the deposits (at least those of known context of discovery) were located on the borders of settlement micro-regions and at local and supra- 
regional routes. He argues, the locations cannot be thus random but were carefully chosen by a given society within or between the commonly recognized and "tamed" settlement networks. Such studies lead to a conclusion the deposits were given complex meaning(s) and cannot be interpreted in simple and discrete economic/ritual/war categories. The offerings (given to supernatural powers/ancestors/nature forces) ordered the space, marked the borders and the transits. The deposition act itself - by reproducing shared norms and relations - stabilized the social life of a group. The deposits located at the borders were means of communication with other groups including prestige demonstration, alliances, independence, partnership in negotiations ect [1].

The second research area developed recently are use-wear microscopic observations of metal objects, particular of tools and weapons which are the base of most Bronze Age deposits. The main question is what the artefacts' biographies were like: how were the bronzes produced, used and deposited. Were they damaged so heavily that deposition was simple scrap-material storage? Was the long usage intention of their makers? Why objects of very poor quality were intensively used while - at least according to our contemporary sense of usefulness- should be melted immediately? In his studies on metal objects' biographies with the use of traceological method, Sych [7,8] argues most of the metal tools and weapons were used in rather moderate way and only some may be considered to be scrap deposits. Although the results are tentative, they seem to confirm the above conclusion on complex nature of Bronze Age deposits which can be analysed on various levels and aspects.

\section{References}

1. Maciejewski M (2016) Metal - Boarder - Ritual. Hoards in Late Bronze Age and Early Iron Age Landscape. In: Kołodziejczyk P and Kwiatkowska-Kopka B (Eds.), Cracow Landscape Monographs 2. Landscape as Impulsion for Culture: Research, Perception \& Protection. Landscape in the Past \& Forgotten Landscapes. Institute of Landscape Architecture Cracow University of Technology, Poland, pp. 263-275.

2. Vandkilde H (1996) From Stone to Bronze: The Metalwork of the Late Neolithic and Earliest Bronze Age in Denmark (Jutland Archaeological Society Publications). Aarhus University Press, Denmark, pp. 490.

3. Bradley R (1998) The Passage of Arms. An Archaeological Analysis of Prehistoric Hoards and Votive Deposits. Oxbow Books, Oxford, the United Kingdom, pp. 234.

4. Blajer W (2001) Skarby przedmiotów metalowych z epoki brązu i wczesnej epoki żelaza na ziemiach polskich. Księgarnia Akademicka, Kraków, Poland, pp. 427.

5. Wojciech B (1997) Beiträgezur Deutung der bronzezeitlichen Hort- und Grabfunde in Mitteleuropa: Materialien der archäologischen Konferenz "Bronzen und Menschen an der Schwelle der Urnenfelderzeit im östlichen Mitteleuropa", Kraków, 05--08.02.1996. Oficyna Cracovia, Kraków, Poland, pp. 254.

6. Wojciech B (2013) Młodsza epoka brązu na ziemiach polskich w świetle badań nad skarbami. Historia Iagellonica, Kraków, Poland, pp. 290.

7. Sych D (2014) Research perspectives of the traceology of metal artifacts. Śląskie Sprawozdania Archeologiczne 56: 31-40.

8. Sych D (2015) Cultural biographies of Bronze Age knives and sickles from south-western Poland. Śląskie Sprawozdania Archeologiczne 57: 115-127.

\section{Your next submission with Juniper Publishers will reach you the below assets}

- Quality Editorial service

- Swift Peer Review

- Reprints availability

- E-prints Service

- Manuscript Podcast for convenient understanding

- Global attainment for your research

- Manuscript accessibility in different formats

( Pdf, E-pub, Full Text, Audio)

- Unceasing customer service

Track the below URL for one-step submission https://juniperpublishers.com/online-submission.php 